\section{Isaac Asimov: centenary of the great explainer}

\section{The chemist and science-fiction visionary championed rationality in 20 million published words. By David Leslie} n 24 December 1968, astronaut William Anders took a photograph of Earth from the observation window of Apollo 8. The picture, now known as Earthrise, became one of the most iconic images in human history - later credited with catalysing the environmental movement. Is Earthrise a product of science or a work of art? Isaac Asimov, the Russian-born chemist and science-fiction colossus (1920-92), had an answer: the two are, in fact, the same.

Asimov spent more than half of the twentieth century cultivating that transformative unity of art and science. He wrote and edited around 500 books and penned myriad stories, articles and essays. They spanned the rich microscopic worlds of cytoplasm, cells and subatomic particles, and ventured into the boundless wilds of space. Throughout, Asimov razed the make-believe boundary between imagination and reason. As he wrote in the gemlike 1978 essay 'Art and Science', the artist's work suffers if knowledge is deficient; the scientist's suffers if leaps of intuition, which so often outpace the leaden trot of rationality, are ignored. Advance in these arenas is often synergistic, and scientists can "make great leaps into new realms of knowledge by looking upon the universe with the eyes of artists".

For Asimov, nurturing ingenuity and insight through exploration, learning and communication was an ethical imperative and crucial for human progress. It was an ethos he promoted through 20 million printed words.

\section{Life of wonder}

Asimov was central to science fiction's Golden Age, as the writer of iconic works such as $I$, Robot (1950), the Foundation series and The Gods Themselves (1972). As a scientist, he was a popularizer who often drew comparisons with H. G. Wells. The leitmotif of his life was an unstinting thirst for knowledge. In Asimov's New Guide to Science (first published as The Intelligent Man's Guide to Science in 1960), he wonderfully characterized the deep history of

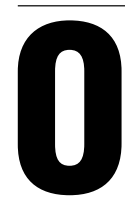

life on Earth as an adventure of curiosity. The book takes us from the clumsy inquisitiveness of an upstart paramecium searching for food several hundred million years ago to the restless seeking that propelled big-brained Homo sapiens into the space age. That brain, the "most magnificently organized lump of matter in the known universe", generates the "curiosity surplus" shaping human culture, he wrote.

Asimov's curiosity was first sparked in the windowless back rooms of a string of Brooklyn sweet shops. Born in 1920 in Petrovichi in Soviet Russia, Asimov was three when he and his family arrived at Ellis Island and began to scrape a living in New York. Three years later, his father had saved enough money to set up the first shop. Young Isaac spent long days delivering newspapers, schlepping boxes and magazines - and reading voraciously. By the age of five, he had taught himself to read by studying street signs. At six, he got his first library card from the Brooklyn Public Library; he would eventually wangle a second one from the neighbouring borough of
Queens, doubling his weekly intake. By his early teens, Asimov was horrifying neighbours as he wended his way blindly down busy streets with his nose in a book and one more under each arm.

Asimov started reading science-fiction at nine, just as the genre had begun ajourney from pulp extravagance to a more science-centred era. He had convinced his father that Hugo Gernsback's magazine Science Wonder Stories contained serious stuff, despite the covers' motley depictions of space ships and aliens. From then on, he would regularly abscond to the shop's storeroom to immerse himself. Thus began a lifelong habit of exploring the open frontiers of possibility in enclosed, electric-lit spaces - not unlike the time-travelling Andrew Harlan (in his 1955 novel The End of Eternity), who zooms across thousands of centuries in a humming "kettle".

\section{The flag of reason unfurled}

A prodigy, Asimov graduated from high school at 15 . He was, however, rejected by Columbia College in Manhattan and directed to Seth Low Junior College, a satellite school in Brooklyn. Anti-Semitism was at work. Undeterred, he plodded through his studies. Meanwhile, a distinctive vision of science fiction as "the literature of social change" took shape in his mind. In 1938, he joined a remarkable sci-fi fan club, the Futurians, along with authors Frederik Pohl, Cyril Kornbluth and Donald Wollheim. The group was progressive and political, opposing the interwar rise of barbarism and militaristic ideologies. It called for science fiction to raise "the torch of science" and unfurl

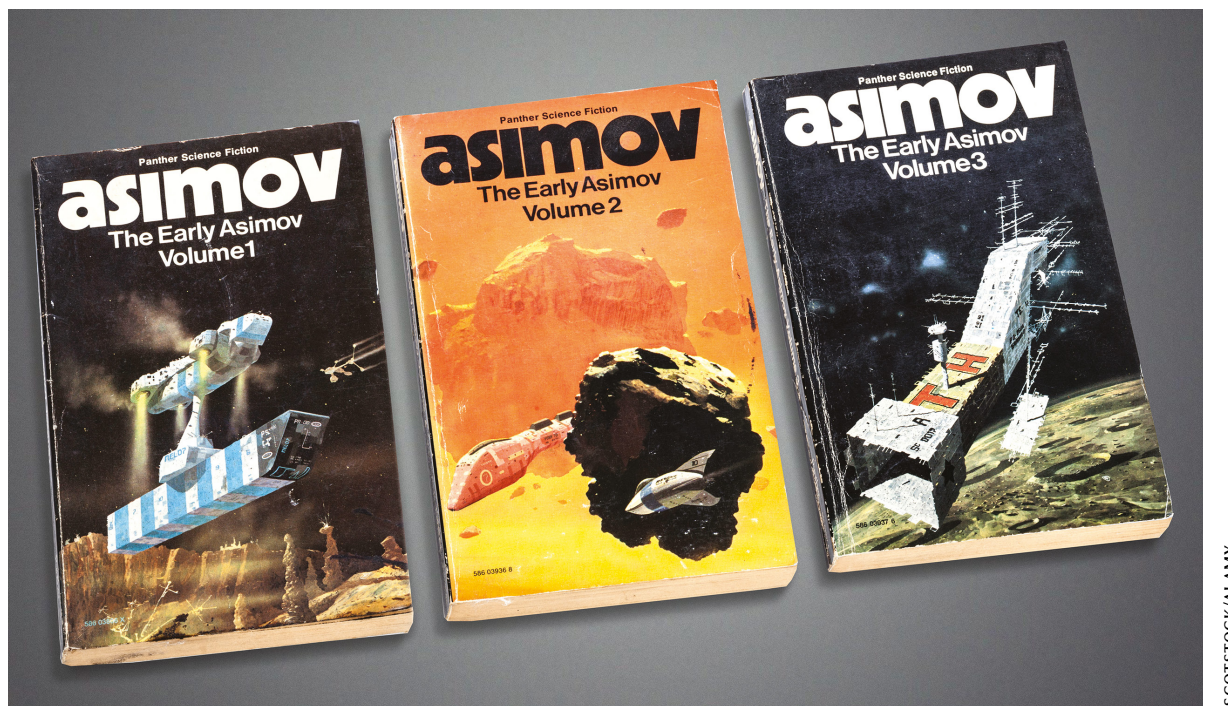

Isaac Asimov published around 500 books, including science-fiction and popular science. 


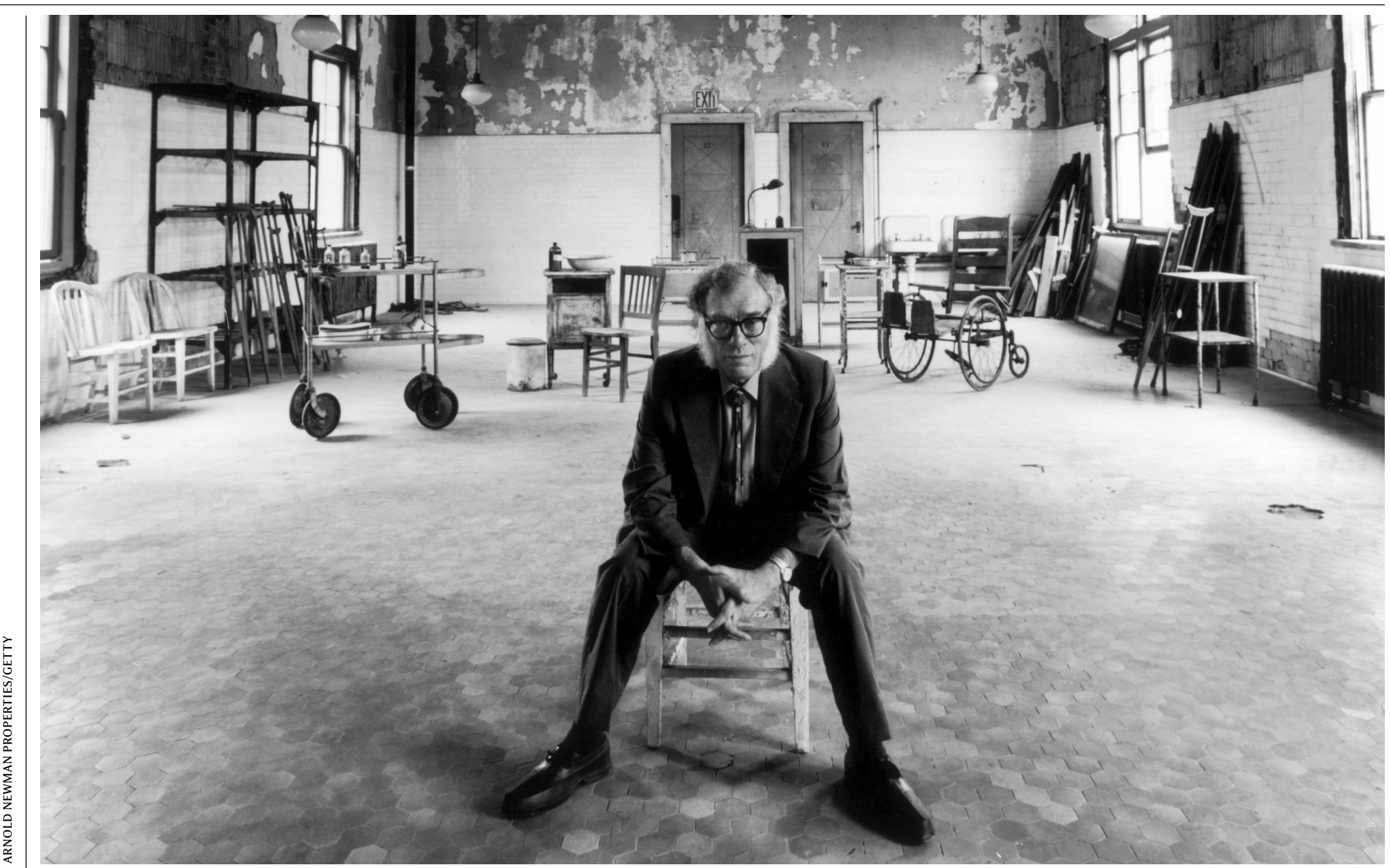

Isaac Asimov in 1982 on Ellis Island, New York.

"the flag of reason" to foster a more united and humane society.

Although he embraced this vision, Asimov felt that an impetus to change needed to be grounded in an understanding of its historical complexities and enabling conditions. He became a student researcher for sociologist Bernhard J.Stern, a co-founder of the journal Science and Society who was completing a book on the social resistance to technological change - Society and Medical Progress, published in 1941. Asimov began to perceive technology as a social institution entangled with others, such as politics and the economy.

He realized that the processes of innovation, which make possible both science fiction and technological progress, are in struggle with the norms and institutions that constrain them. He saw that the modern "era of change" was the crucible for this struggle, as scientists and artists envisioned and created futures and realities radically different from the past.

This conflict became Asimov's creative launchpad. Science fiction in his hands dove headlong into the eye of the societal storm, where future-facing human ingenuity

\section{"Science fiction in his hands dove headlong into the eye of the societal storm."}

confronts the prevailing cultural patterns and historical conditions that determine the possibilities of the present.

\section{To the stars}

Asimov's star began its spectacular rise. While still an undergraduate, he published his first sci-fi piece, 'Marooned Off Vesta', in the magazine Amazing Stories. The freshly shaven 18-year-old Asimov had also shown up, manuscript in hand, at the door of the legendary editor of Astounding Science Fiction, John W. Campbell. Although Campbell gracefully turned down the story, he became Asimov's greatest literary mentor. Their relationship ended up tense and complicated, however, with Asimov explicitly rejecting Campbell's fascist politics and belief in racial superiority. (It must be noted here that Asimov had his own egregious behaviour: the unapologetic harassing of women.)

With Robert Heinlein and Arthur C. Clarke, among others, Asimov ushered in a turn towards technically sophisticated science fiction, inspiring readers to move beyond the escapist era of ray guns and romance to critically embrace the computer revolution and the coming space age.

Asimov's annus mirabilis spanned 1941 and 1942. He published 'Nightfall' in Astounding, a metaphor for humankind's devastating psychological confrontation with its own cosmic insignificance. In 1968, the Science Fiction Writers of America voted it one of the greatest sci-fi stories ever penned. He also produced several of his celebrated robot stories - such as 'Reason', 'Liar' and 'Runaround' - in which he coined the term robotics (after the robots of R.U.R (Rossum's Universal Robots), a play by Czech writer Karel Čapek, published 100 years ago) and famously invented the field's three ethical laws. Those accomplishments are honoured every April in the United States, during National Robotics Week.

And 1942 saw the publication of 'Foundation', 


\section{Books \& arts}

the inaugural instalment of Asimov's eponymous series and a masterwork of future history modelled on Edward Gibbon's eighteenth-century classic, The History of the Decline and Fall of the Roman Empire. In the series, humanity battles against a galactic descent into 30,000 years of barbarism, foretold by the statistical science of 'psychohistory'. The epic is rife with the struggles of human agency against the "dead hand of social inevitability" - themes still unnervingly relevant in today's algorithm-driven 'big data' society. In 1966, the Foundation trilogy won a Hugo Award for the best science-fiction series ever written.

\section{Responsibility of communication}

The next decade was a busy one. Asimov worked as a scientist for the US Navy during the Second World War; completed a doctorate in chemistry at Columbia; and, in 1949, took a post teaching biochemistry at Boston University School of Medicine in Massachusetts. Even as his science-fiction career gathered pace, his academic role nudged him towards science writing, beginning with the co-authored 800-page Biochemistry and Human Metabolism in 1952. Six books on chemistry followed, along with a run of sparkling popular-science essays with beguiling titles such as 'The Explosions Within Us' and 'The Abnormality of Being Normal'.

On 4 October 1957, the world was galvanized as the Soviet Union propelled the 84-kilogram satellite Sputnik 1 into elliptical Earth orbit. In the United States, panic rose over the gap in research progress. As US citizens turned on short-wave radios to listen for its eerie 'beep-beep', Sputnik mania sparked a massive demand for educational popular-science writing - and a shift towards a more unified vision of Earth. Nature ended and Ecology was born, the media theorist Marshall McLuhan later noted: "The planet became a global theater in which there are no spectators but only actors. On Spaceship Earth there are no passengers; everybody is a member of the crew."

Asimov plunged into both educating the public and advocating a sustainable future. In 1958, he switched to mainly writing science books. The following year, he wrote half a million words in eight months, culminating in The Intelligent Man's Guide to Science, nominated for the 1960 National Book Award.

Across his non-fiction, Asimov dedicated himself to initiating lay readers into the world of scientific exploration through unadorned but wonder-filled writing. The aim was to allow them to weigh up the prospects and challenges of scientific advance lucidly and capably. Astronomer and science communicator Carl Sagan's obituary of Asimov in Nature calls him "one of the great explainers of the age", motivated by a "profoundly democratic impulse" (C. Sagan Nature 357, 113; 1992).

Asimov himself dubbed that impulse the

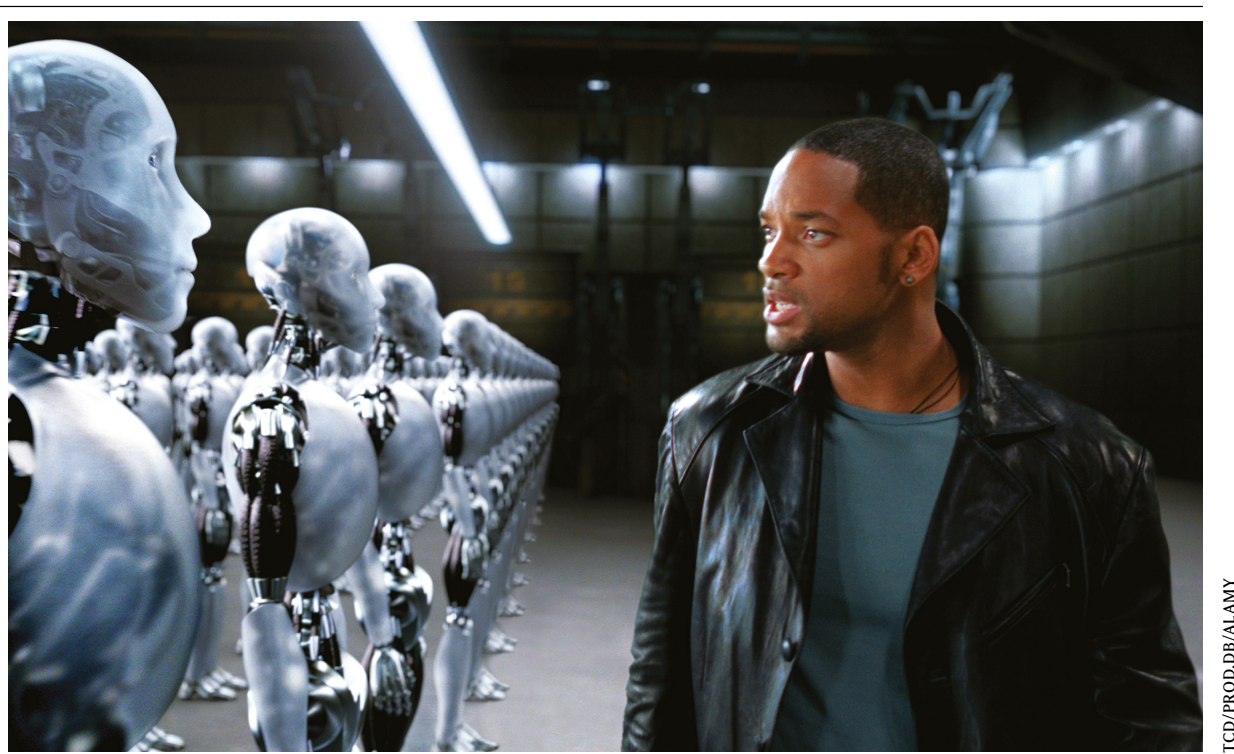

Will Smith in Alex Proyas's film I, Robot (2004), based on Asimov's fiction.

"responsibility of communication". In a 1988 interview, he explained that it rested on the fact "that science is tentative, that it is not certain, that it is subject to change". Therefore, no voice can have the last word, and open, inclusive and rational communication is the only option for advancement. The public, meanwhile, bears the "responsibility of listening".

These strains of Enlightenment thinking made him a staunch critic of pseudoscience,

\section{"Asimov wrote: ‘Science gathers knowledge faster than society gathers wisdom."'}

intolerance and superstition. He spent a good part of his final years championing secular reason in an age when, he believed, the candle of critical thinking had dimmed. In 1988, he observed: "the saddest aspect of life right now is that science gathers knowledge faster than society gathers wisdom".

\section{The good Earth is dying}

Asimov recognized that this troubling disconnect had grave planetary consequences. In his perceptive 1971 essay 'The Good Earth Is Dying', he pointed out that, with accelerating technological advancement, harmful impacts on society and the environment had already reached a global scale. Meanwhile, attitudes such as the reverence for limitless growth and the embrace of tribalism persisted - dictated by antiquated parochial beliefs and local conventions, rather than being transposed in a global key and altered accordingly. Asimov wrote: "What was common sense in a world that once existed has become myth in the totally different world that now exists, and suicidal myth at that".
Many decades before the rise of idioms of anxious sociotechnical reflection such as 'the sixth extinction', or the 'Anthropocene epoch', Asimov was writing about how "anthropogenic processes" were poisoning the planet. From the 1970s onwards, he wrote about how atmospheric pollution was destroying the ozone layer, acidifying the oceans and exacerbating the scale of natural catastrophes. He described human-driven global warming and its probable effects on the biosphere. He noted how overpopulation and the sweep of reckless human activities were prompting a "great die-off" of species at an unprecedented rate.

Asimov called for global solutions to global problems, anchored in a vision of humanity united by a common aim. That stance drove him from the start. More than a decade before Earthrise so stirringly revealed our planetary home, Asimov, in the 1953 essay 'Social Science Fiction', reflected on how literature portraying a multitude of worlds puts ours into perspective. In a conceptually vast Universe, Earth shrinks, to beneficial effect: subdivisions that ordinarily polarize can become much harder to perceive or conceive, and humanity can be seen as faced with "common dangers and common tasks".

A century after Asimov's birth, forests burn from Australia to California. Shorelines are swallowed by rising seas, towns ravaged by unearthly storms. Humanity's insatiable appetites continue to crush the diversity of life, and conflicts draw us ever closer to a fiery end. At such a juncture, we might do well to pick up Asimov's writings and take flight with him. Perhaps then we can together peer back at our pale blue island, suspended in the void, and gain a saner, more humane and more rational point of view.

David Leslie is the Ethics Fellow at the Alan Turing Institute in London. e-mail: dleslie@turing.ac.uk 


\section{Books \& arts}

\section{Correction}

Isaac Asimov: centenary of the great

explainer

This article should have noted that Asimov had his own egregious behaviour: his unapologetic harassing of women.

See https://doi.org/10.1038/d41586-020-

00176-4 